\title{
Effects of Hydrogen Sulfide on Bacterial Communities on the Surface of Galatheid Crab, Shinkaia crosnieri, and in a Bacterial Mat Cultured in Rearing Tanks
}

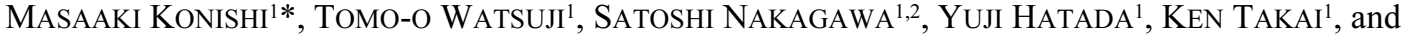 \\ TAKASHI TOYOFUKU ${ }^{1}$ \\ ${ }^{1}$ Institute of Biogeoscience (Biogeos), Japan Agency for Marine-Earth Science and Technology (JAMSTEC), 2-15 \\ Natsushima-cho, Yokosuka, Kanagawa 237-0061, Japan; and ${ }^{2}$ Faculty of Fisheries Sciences, Hokkaido University, 3- \\ 1-1 Minato-cho, Hakodate, Hokkaido 041-8611, Japan
}

(Received March 27, 2012—Accepted July 12, 2012_Published online October 19, 2012)

To investigate the effects of $\mathrm{H}_{2} \mathrm{~S}$ on the bacterial consortia on the galatheid crab, Shinkaia crosnieri, crabs of this species were cultivated in the laboratory under two different conditions, with and without hydrogen sulfide feeding. We developed a novel rearing tank system equipped with a feedback controller using a semiconductor sensor for hydrogen sulfide feeding. $\mathrm{H}_{2} \mathrm{~S}$ aqueous concentration was successfully maintained between 5 to $40 \mu \mathrm{M}$ for $80 \mathrm{~d}$ with the exception of brief periods of mechanical issues. According to real-time PCR analysis, the numbers of copies of partial 16S rRNA gene of an episymbiont of the crabs with $\mathrm{H}_{2} \mathrm{~S}$ feeding was three orders of magnitude larger than that without feeding. By phylogenetic analysis of partial 16S rRNA gene, we detected several clones related to symbionts of deep sea organisms in Alphaproteobacteria, Gammaproteobacteria, Epsilonproteobacteria, and Flavobacteria, from a crab with $\mathrm{H}_{2} \mathrm{~S}$ feeding. The symbiont-related clones were grouped into four different groups: Gammaproteobacteria in marine epibiont group I, Sulfurovum-affiliated Epsilonproteobacteria, Osedax mucofloris endosymbiont-affiliated Epsilonproteobacteria, and Flavobacteria closely related to CFB group bacterial epibiont of Rimicaris exoculata. The other phylotypes were related to Roseobacter, and some Flavobacteria, seemed to be free-living psychrophiles. Furthermore, white biofilm occurred on the surface of the rearing tank with $\mathrm{H}_{2} \mathrm{~S}$ feeding. The biofilms contained various phylotypes of Gammaproteobacteria, Epsilonproteobacteria, and Flavobacteria, as determined by phylogenetic analysis. Interestingly, major clones were related to symbionts of Alviniconcha sp. type 2 and to endosymbionts of Osedax mucofloris, in Epsilonproteobacteria.

Key words: hydrogen sulfide, epibiont, symbiont, tank, feedback control

The chemoautotrophic ecosystem is supported by chemoautotrophs, which are organisms that are capable of fixing carbon using chemical energy obtained from the oxidation of reduced compounds blowing up from hydrothermal vents, such as sulfuric compounds, methane, and hydrogen (18). Several benthic invertebrates are hosts of chemoautotrophic bacteria in cells of specialized tissues and on the surface of their bodies, and they obtain nutrition from the bacteria (2).

Shinkaia crosnieri, a galatheid crab, is one of the most predominant animal species that massively aggregate close to hydrothermal vents on the subseafloor in the deep sea. The crab is observed only in areas near active vents in the Okinawa Trough, western Pacific $(25,26)$. The crab has not only strong, stout, sparse setae on the dorsal surface of its carapace, chelipeds, and walking legs, but also long, soft, dense plumose setae on the ventral surface of its body (1). According to previous studies $(27,30)$, epibiotic filamentous symbionts inhabit the surface of the plumose. Phylogenetic analyses of $16 \mathrm{~S}$ rRNA sequences in those studies showed no significant difference in the epibiotic phylotype composition of the individuals collected from different sites. The major

\footnotetext{
* Corresponding author. E-mail: konishi-masaaki@jamstec.go.jp; Tel: +81-46-867-9661, Fax: +81-46-867-9645.
}

subdivisions of the phylotypes were Epsilonproteobacteria and Gammaproteobacteria. In particular, specific phylogenetic clusters related to the genus Sulfurovum have been found in epibiotic 16S rRNA gene clone libraries. A freeliving Sulfurovum sp. NBC37-1 isolated from a vent field is one of the most well-characterized strains (17, 31). According to whole genome sequencing (17), NBC37-1 is a mesophilic hydrogen- and sulfur-oxidizing chemolithoautotoroph and has key genes associated with sulfur reduction ( $p s r$ families) and oxidation (sox families). Further culturedependent experiments showed that the strain can grow utilizing two different types of sulfur related energy metabolism, namely, hydrogen-oxidizing sulfur respiration and thiosulfate-oxidizing nitrate/oxygen respiration in the deep sea (17). Such experiments also provide evidence for the operation of the hydrogenase-coupled polysulfide reductase pathway as well as the Sox system; therefore, the strain and its relatives may inhabit the mixing zones between oxidative and reductive areas where the physical and chemical conditions are optimal for sulfur-oxidizing nitrate/oxygen and hydrogen-oxidizing respiration (31).

On the other hand, Saito (21) reported that Shinkaia crosnieri obtains many of its lipids from Bathymodiolus mussels and chemosynthetic symbionts on the basis of the characteristics of fatty acid composition of the crab. Miyake 
et al. (15) have reported that the crabs graze on epibiotic bacteria using their mouth-parts in a tank rearing system with an artificial hydrothermal vent system; therefore, we consider that the crab is able to obtain many nutrients from episymbionts on its surface. However, there has been no information on how environmental, physical and chemical conditions affect the episymbiont consortium on the surface of the crab, since it is difficult to control experimental conditions, particularly $\mathrm{H}_{2} \mathrm{~S}$ concentration, in the laboratory. The continuous supply of hydrogen sulfide, which is a highly poisonous and reactive gas, at low levels has also been difficult.

In the applied microbiology research field, there have been reported high cell density cultivation techniques with feedback control of volatile and toxic materials such as alcohols at a low level in a jar fermenter by detecting evaporated compounds in the exhaust gas by a semiconductor sensor $(6$, 9). We applied technology for the $\mathrm{H}_{2} \mathrm{~S}$ control system of the rearing tank for deep-sea invertebrates, which is also capable of controlling temperature and dissolved oxygen. Using the newly developed rearing tank system, we first examined the effect of low-concentration $\mathrm{H}_{2} \mathrm{~S}$ on episymbiotic bacterial communities in an artificial environment. The aim of this experiment was to examine the effects in clear cause-effect relationships between $\mathrm{H}_{2} \mathrm{~S}$ and bacterial communities by novel controlled growth conditions in the rearing tanks. Moreover, a white bacterial mat was obtained from the surface of the rearing tank. On the basis of the results of phylogenetic analysis, we also describe here the bacterial consortium structure. Finally, we discuss the effects of hydrogen sulfide on deep-sea bacteria and the potential use of the rearing tank experimental system.

\section{Materials and Methods}

\section{Collection of S. crosnieri from deep-sea vent}

Individuals of $S$. crosnieri were collected from a deep-sea hydrothermal field: Iheya North field $\left(27^{\circ} 47.46^{\prime} \mathrm{N}, 126^{\circ} 53.80^{\prime} \mathrm{E}\right.$, depth $=981 \mathrm{~m}$ ) in the Okinawa Trough, Japan, by a remotely operated vehicle (ROV), 'HyperDolphin' of Japan Agency for Marine-Earth Science and Technology (JAMSTEC). The individuals collected, which were still alive after the rapid pressure and temperature change during recovery, were immediately moved to shipboard tanks containing surface seawater at $4^{\circ} \mathrm{C}$.

\section{Rearing tanks for $\mathrm{S}$. crosnieri.}

Fig. 1A shows the rearing tank system including the $\mathrm{H}_{2} \mathrm{~S}$ feeding system (gas sensor, feedback control system, and gasproviding apparatuses), temperature control system (a thermostat controller and a cooler), and dissolved oxygen (DO) control system (DO sensor, mixing pump, and degassing system). The main tank of 100 and $200 \mathrm{~L}$ and their lids (1 in Fig. 1A) were made of acryl plastic plates from Iwaki Pumps (Tokyo, Japan). The tin dioxide semiconductor sensor unit for $\mathrm{H}_{2} \mathrm{~S}$ (2 in Fig. 1A, TGS-825; Figaro Eng., Osaka, Japan) was equipped with an electric circuit unit placed inside the lid of the rearing tank. The sensor detected $\mathrm{H}_{2} \mathrm{~S}$ in the head space of the tank as voltage signals. The signals are approximately proportional to the $\mathrm{H}_{2} \mathrm{~S}$ concentration in tank water (Fig. 1B). The sensor was connected to a detection relay (3 in Fig. 1A, 2411D-1-04-H0-T5-A; Tsuruga Electric, Osaka, Japan) and a data logger (4 in Fig. 1A, LR5042; Hioki, Nagano, Japan). An electromagnetic valve and a pump were controlled by on-off signals by the detect relay. Hydrogen sulfide gas was provided from the cylinder of liquefied $\mathrm{H}_{2} \mathrm{~S}$ via the valve to a gas exchange unit ( 8 in Fig. 1A, STERAPORE degassing module, MHF0504MBFT; Mitsubishi Rayon, Tokyo, Japan). The gas was dissolved in water that passed through the unit. The water was degassed by a gas trap (9 in Fig. 1A) and introduced into a porous tetrafluoroethylene (PTFE) tube (10 in Fig. 1A, POREFLON tube, TB-0302; Sumitomo Electric Fine Polymer, Tokyo, Japan), and circulated to the gasexchange unit. The dissolved $\mathrm{H}_{2} \mathrm{~S}$ was diffused from the circulating water to the tank water via the PTFE tube and sea sand bed (11 in Fig. 1A). The $\mathrm{H}_{2} \mathrm{~S}$ concentration in the tank water was controlled to between 20 and $50 \mu \mathrm{mol} \mathrm{L}^{-1}$. The concentration was set to avoid chemical generation of white matter in the tank water by $\mathrm{H}_{2} \mathrm{~S}$ in preparatory experiments, because the optimal concentration for the crabs was unknown. The concentration of $\mathrm{H}_{2} \mathrm{~S}$ in the Iheya North field has been reported to be over a wide range from $2.6 \mathrm{mmol} \mathrm{kg}^{-1}$ to not detected (7). A digital optical sensor (Oxymax W COS61D; Endress+Hauser, Switzerland) was used for detecting DO. The signals were analyzed by a transmitter (Liquisis M COM223; Endress+Hauser). The aeration pump (14 in Fig. 1A) and degassing system (16, 17, and 18 in Fig. 1A) were controlled by the transmitter. DO was controlled by the system at between 1.0 and $1.5 \mathrm{mg} \mathrm{L}^{-1}$, which corresponds to between 8.12 and $12.2 \%$ of saturation at $5.2{ }^{\circ} \mathrm{C}$. $\mathrm{pH}$ was continuously measured by a pH sensor (MicropH; Aquabase, Kanagawa, Japan). Temperature was controlled at $5.25 \pm 2.5^{\circ} \mathrm{C}$ by a

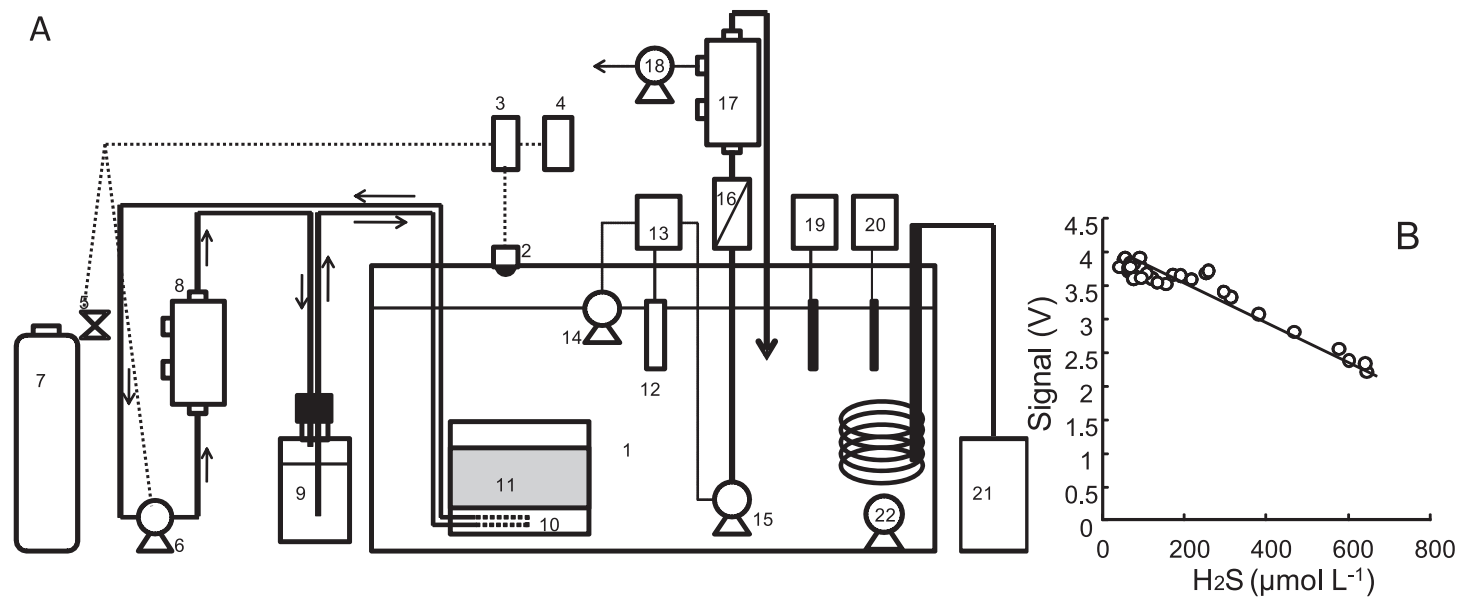

Fig. 1. Schematic illustration of experimental setup, A. 1: rearing tank, 2: gas sensor unit, 3: detect relay, 4: data logger, 5: electromagnetic valve, 6: pump, 7: cylinder of liquid hydrogen sulfide, 8: gas-exchange unit, 9: gas trap, 10: porous PTFE membrane tube, 10: bed of sea sand, 12: DO sensor, 13: DO terminator, 14: aeration pump, 15: pump, 16: EHEIM filter, 17: degassing unit, 18: degassing pump, 19: pH meter, 20: thermostat, 21: cooling unit, and 22: pump. Plots of gas sensor signals versus hydrogen sulfide concentrations in tank water, B. 
thermostat controller (TC-100; Iwaki Pumps) and a cooling unit (AZ-151X; Iwaki Pumps). Artificial seawater (ROHTOMARINE II; Iwaki Pumps) was used as the tank water. For a comparative experiment without $\mathrm{H}_{2} \mathrm{~S}$ feeding, a tank without an $\mathrm{H}_{2} \mathrm{~S}$ feeding system (2 to 11 in Fig. 1A) was also prepared. Sixty crabs were transferred to $200-\mathrm{L}$ tanks with an $\mathrm{H}_{2} \mathrm{~S}$ feeding system, and thirty crabs to a $100-\mathrm{L}$ tank without a feeding system.

\section{Determination of $\mathrm{H}_{2} \mathrm{~S}$ concentration in tank water}

A colorimetric method for the quantification of $\mathrm{H}_{2} \mathrm{~S}$ concentration in tank water was carried out by a previously reported method (32) with modification. $N, N$-dimethyl- $p$-phenylene diammonium dichloride $(14.3 \mathrm{mM})$ and $\mathrm{FeCl}_{3}(18.5 \mathrm{mM})$, solutions were prepared in $0.6 \mathrm{M} \mathrm{HCl}$ as test reagents. One milliliter of tank water was gently mixed with $0.1 \mathrm{~mL}$ of a test reagent. The samples were incubated at room temperature for $5 \mathrm{~min}$. The absorbance of the samples at $670 \mathrm{~nm}$ was measured by a spectrometer (UV-1000; Hitachi, Tokyo, Japan).

\section{Microscopy}

Microscopy was carried out using microscope systems (Eclipse E600, Nikon, and Olympus BX51 systems) equipped with a digital camera. Then, 4',6-diamidine-2'-phenylindole dihydrochloride (DAPI)-stained samples were prepared as follows. Samples of the setae of $S$. crosnieri crabs and biofilms were collected in deionized water and centrifuged at $10,000 \times \mathrm{g}$ for $1 \mathrm{~min}$. The supernatant was removed and the samples were washed in $1 \mu \mathrm{g} \mathrm{mL}-1$ DAPI in methanol solution and covered for $15 \mathrm{~min}$ at room temperature with DAPI solution. DAPI solution was removed by centrifugation, and the setae were then gently washed with methanol immediately. The washed samples were redispersed in phosphate-buffered saline $\mathrm{pH}$ 6.8 ) and used for microscopy.

\section{DNA extraction}

Samples of the setae of $S$. crosnieri (approximately $20 \mathrm{mg}$ wet weight) were collected immediately after washing the crabs with filtered artificial sea water, and centrifuged at $9,100 \times \mathrm{g}$ for $1 \mathrm{~min}$. The supernatant was removed carefully. Wet weight of a portion of setae samples was measured. Genomic DNA of samples were extracted from setae immediately by a DNA extraction kit for soil (ISOIL for Beads Beating; Nippon Gene, Tokyo, Japan). Extraction was carried out following the manufacturer's instructions.

\section{Real-time PCR analysis}

To estimate the population of bacteria on the setae of the crabs, which were cultivated with and without feeding with $\mathrm{H}_{2} \mathrm{~S}$, real-time PCR was performed. A SYBR Premix Ex Taq II kit (Takara Bio, Shiga, Japan) was used for real-time PCR analysis. Partial 16S rRNA gene sequences as target genes were amplified by PCR using the SYBR Premix Ex Taq II system with the universal primers Bac341F (3'-CCTACGGGAGGCAGCAGTGA-5') and Bac534R (3'-CGTATTACCGCGGCTGCTG-5'). Thermal cycling and light detection were performed using the ABI Prism 7500 system (Applied Biosystems, Foster City, CA, USA), with preliminary denaturation at $94^{\circ} \mathrm{C}$ for $4 \mathrm{~min}$, followed by 40 cycles of denaturation at $94^{\circ} \mathrm{C}$ for $30 \mathrm{~s}$, annealing at $55^{\circ} \mathrm{C}$ for $30 \mathrm{~s}$, and elongation at $72^{\circ} \mathrm{C}$ for 34 $\mathrm{s}$, and following the melt curve stage, denaturation at $95^{\circ} \mathrm{C}$ for 15 $\mathrm{s}$, annealing at $60^{\circ} \mathrm{C}$ for $1 \mathrm{~min}$, and denaturation at $95^{\circ} \mathrm{C}$ for $15 \mathrm{~s}$. Standard DNA solutions $\left(1.2 \times 10^{3}\right.$ to $1.2 \times 10^{9}$ copies $\left.\mu \mathrm{L}^{-1}\right)$ was prepared from genomic DNA of Escherichia coli HB101 by PCR amplification using ABI GeneAmp PCR System 2700 (Applied Biosystems) with Bac341F and Bac534R primers. A Qubit Assay kit and a Qubit fluorometer were used for the quantification of standard DNA. Quantification was carried out in accordance with the manufacturers' instructions. The amount of bacteria against wet weight was calculated as the number of copies per gram from $C t$ of individual reaction curves using the standard program of $\mathrm{ABI}$ Prism 7500. Real-time PCR analysis was performed three times for three individuals.

\section{Phylogenetic analysis}

To analyze epibiotic clones on the surface of the crabs, the obtained real-time PCR products were used directly as follows. The products were purified using the Wizard SV Gel and PCR CleanUp System (Promega Corporation, Madison, WI, USA). Purified products were cloned using a TA cloning kit (QIAGEN PCR Cloning ${ }^{\text {plus }}$ kit; QIAGEN, Germany) in accordance with the manufacturer's instructions. The recombinant colonies were transferred to LB medium with $50 \mu \mathrm{g} \mathrm{mL}^{-1}$ ampicillin and incubated at $37^{\circ} \mathrm{C}$ overnight. Recombinant plasmids were extracted using the QIAprep Miniprep system (QIAGEN) and sequenced with an ABI PRISM 3100 DNA Analyzer and an BigDye Terminator Cycle Sequencing kit, version 3.1 (PE Biosystems, Foster City, CA, USA). In the analysis of bacterial biofilms, 16S rRNA gene sequences were amplified with the bacterial 16S rRNA-universal oligonucleotide primers Bac27F and Univ1492R (11). Thermal cycling was performed using a GeneAmp PCR System 2700 (Applied Biosystems), with preliminary denaturation at $94^{\circ} \mathrm{C}$ for $4 \mathrm{~min}$, followed by 27 cycles of denaturation at $94^{\circ} \mathrm{C}$ for $30 \mathrm{~s}$, annealing at $55^{\circ} \mathrm{C}$ for $30 \mathrm{~s}$, and elongation at $72^{\circ} \mathrm{C}$ for $2 \mathrm{~min}$, and a final elongation at $72^{\circ} \mathrm{C}$ for $7 \mathrm{~min}$. The amplified $16 \mathrm{~S}$ rRNA gene products were cloned using the above TA cloning kit. The TA clones were used for sequencing and phylogenetic analysis. Single phylogenetic clone types (phylotypes) were obtained from the sequence analyses. The phylotypes were compared with those of related sequences obtained from DNA Data Bank, Japan (DDBJ) and GenBank of the National Center for Biotechnology Information via the BLAST search program and aligned using Clustal $\mathrm{X}$ ver. 2.0 software by the neighbor-joining method (12). The phylogenetic tree was visualized using TreeView software version 1.6.6.

\section{Nucleotide sequence accession numbers}

The sequence data have been submitted to EMBL/GenBank/ DDBJ databases under accession numbers AB697010 to AB697038.

\section{Results}

\section{Cultivation of $\mathrm{S}$. crosnieri with epibionts}

To investigate the effects of $\mathrm{H}_{2} \mathrm{~S}$ feeding that are separate from the other effects, including hydrostatic pressure, temperature, and the other chemicals as far as possible, $S$. crosnieri crabs were cultivated in rearing tanks with and without $\mathrm{H}_{2} \mathrm{~S}$ feeding. The temperature and $\mathrm{DO}$ of the rearing tank without $\mathrm{H}_{2} \mathrm{~S}$ feeding were maintained at $5^{\circ} \mathrm{C}$ and $1 \mathrm{mg}$ $\mathrm{L}^{-1}$ as set points during the cultivation period. $\mathrm{pH}$ was kept at approximately 8.0 during cultivation periods (data not shown). Fig. 2 indicates the parameters measured during the cultivation with $\mathrm{H}_{2} \mathrm{~S}$ feeding. Four crabs died $1 \mathrm{~d}$ after starting cultivation when $\mathrm{H}_{2} \mathrm{~S}$ was not fed into the tank; stress during shipping probably affected these dead crabs. In the early phase of cultivation (first week), the effects of $\mathrm{H}_{2} \mathrm{~S}$ on the activities of the crabs were examined. $\mathrm{H}_{2} \mathrm{~S}$ was initially introduced in pulses until an $\mathrm{H}_{2} \mathrm{~S}$ concentration of approximately $100 \mu \mathrm{mol} \mathrm{L}{ }^{-1}$ was reached in the tank water (Fig. 2A). The concentration of this compound increased rapidly during feeding and decreased markedly after stopping the feeding. The rapid decrease in $\mathrm{H}_{2} \mathrm{~S}$ concentrations may have mainly been due to the spontaneous oxidization of $\mathrm{H}_{2} \mathrm{~S}$. The initial pulse introduction of the compound did not have harmful effects on the survival of the crabs (Fig. 2C). Then, $\mathrm{H}_{2} \mathrm{~S}$ was continuously introduced into the tank, and its concentration was maintained between 5 and $60 \mu \mathrm{mol} \mathrm{L}-1$ by the feedback control system. Feeding was successfully maintained before the cooling unit malfunctioned $36 \mathrm{~d}$ 
after starting the cultivation. During the period before the malfunction, the temperature of the tank water was well controlled at $5.2 \pm 0.2^{\circ} \mathrm{C}$, and DO concentration initially decreased to approximately $1 \mathrm{mg} \mathrm{L}^{-1}$ in the initial $7 \mathrm{~d}$ (Fig. 2B). The decrease in DO concentration may have been caused by not only the degassing-DO control system, but also the respiration of crabs and aerobic bacterium. $\mathrm{pH}$ gradually decreased from 7.95 to 7.45 during the same period (Fig. 2B). Unfortunately, the malfunction of the cooling unit markedly increased the tank temperature to $12.6^{\circ} \mathrm{C}$ for several hours, which killed four crabs. We immediately transferred the active crabs into the back-up rearing tank system; therefore, DO concentration primarily increased to approximately saturation. The increased DO concentration gradually decreased to approximately $1 \mathrm{mg} \mathrm{L}^{-1}$ in the following $5 \mathrm{~d}$. $\mathrm{pH}$ also increased to 8.2 in the new artificial sea water, and gradually decreased. Three additional crabs died during the period between the $43 \mathrm{rd}$ day and the 55 th day. It was possible that the death of the crabs was caused by the high temperature following the malfunction of the cooling unit. Finally, 44 of
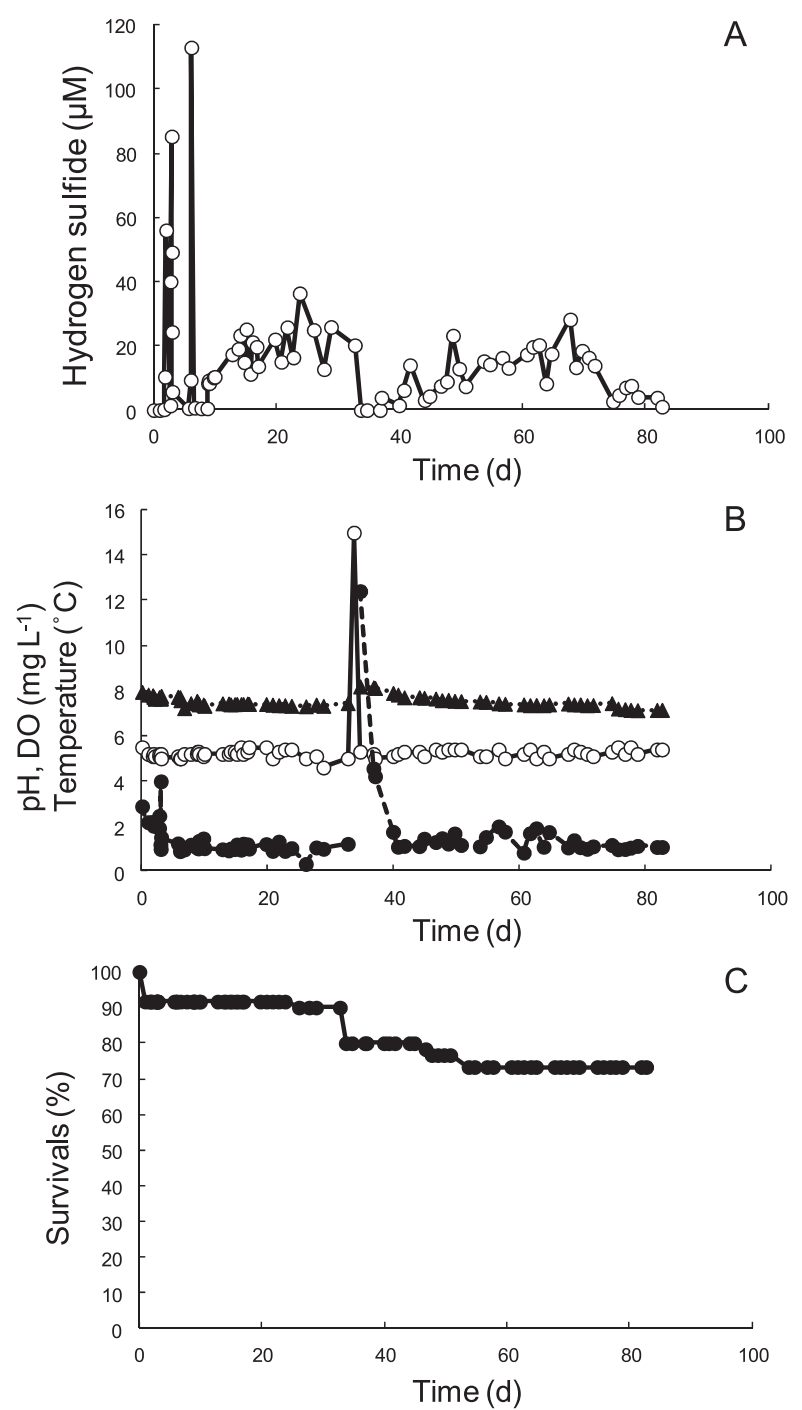

Fig. 2. Time courses of $\mathrm{H}_{2} \mathrm{~S}$ concentration, $\mathrm{pH}$, DO concentration, temperatures, and survival rate. Time courses of $\mathrm{H}_{2} \mathrm{~S}$ concentration (A), $\mathrm{pH}, \mathrm{DO}$, and temperature (B), and survival rate of the crab as a percentage (C). Symbols: pH $(\mathbf{\Delta})$, DO $(\mathbf{O})$, and temperatures $(\bigcirc)$. the initial 60 crabs remained (survival of crabs was $73.3 \%$ ) after $84 \mathrm{~d}$ of cultivation when the crabs were cultivated with $\mathrm{H}_{2} \mathrm{~S}$ feeding. On the other hand, 27 of the initial $30 \mathrm{crabs}$ survived (survival of crabs was $90.0 \%$ ) when the crabs were cultivated without $\mathrm{H}_{2} \mathrm{~S}$ feeding (data not shown). The survival rate of crabs with $\mathrm{H}_{2} \mathrm{~S}$ feeding seemed to be lower than that of crabs without $\mathrm{H}_{2} \mathrm{~S}$ feeding. Active busy setae were observed a few days after continuous feeding of $\mathrm{H}_{2} \mathrm{~S}$, and their color changed from brown to cream. Furthermore, white bacterial films (biofilm) formed and increased on the surface of the tank wall (Fig. 3A) and sea sand in the feeding unit (Fig. 3B) (11 in Fig. 1A).

\section{Estimation of amount of epibionts on surface of setae}

To estimate the amount of epibiotic bacteria on the surface of setae of crabs with and without $\mathrm{H}_{2} \mathrm{~S}$ feeding after

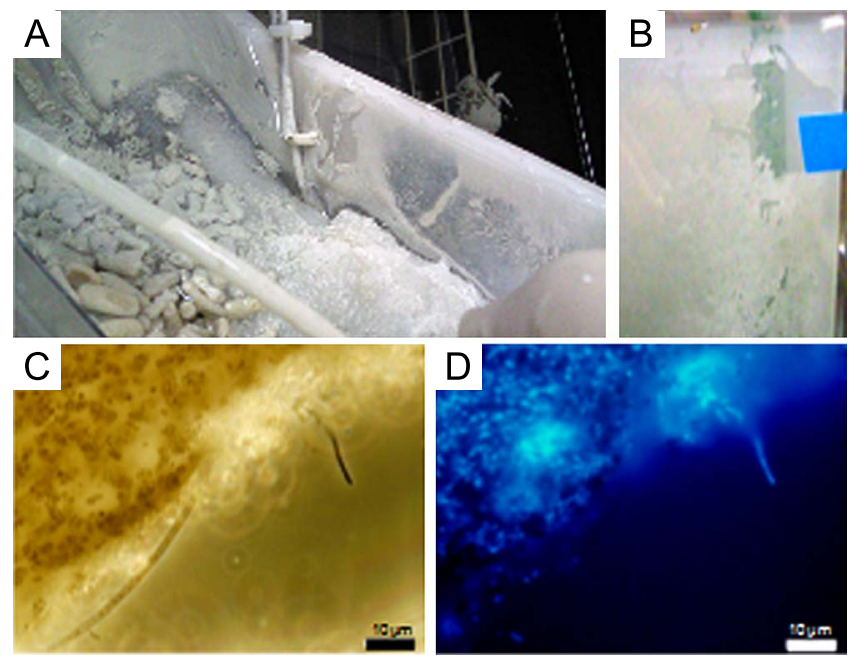

Fig. 3. Images of biofilms. Image of biofilm occurring on the surface of the tank wall (A), image of biofilm occurring on the surface of the sea sand bed (B, 11 in Fig. 1A), phase difference microscopy image of a portion of biofilm (C), and epifluorescence microscopy image of a portion of DAPI-stained biofilm (D).
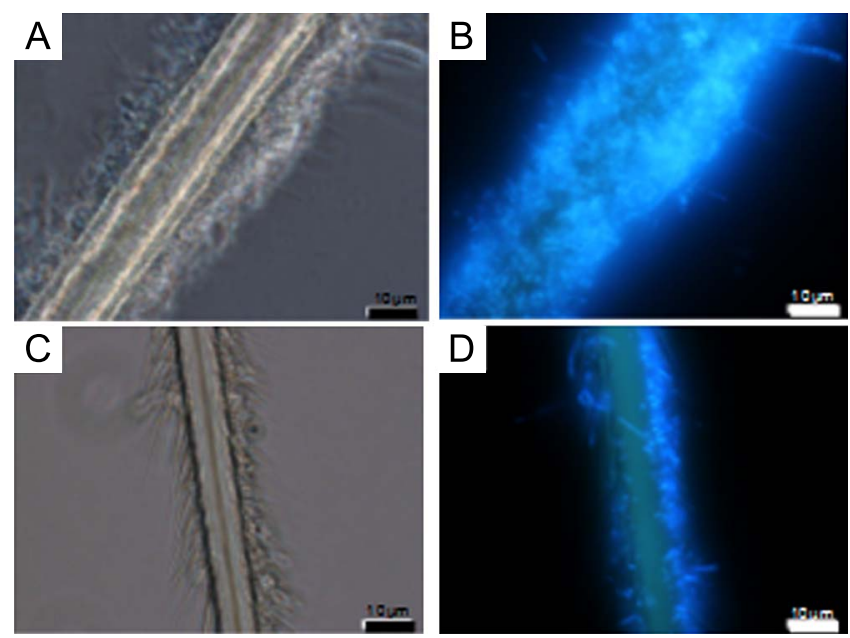

Fig. 4. Microphotographs of setae of crabs with and without $\mathrm{H}_{2} \mathrm{~S}$ feeding. Images of setae of crabs with feeding (A and B) and without feeding $(C$ and $D)$ are shown. Phase difference microscopic images $(A$ and C) and DAPI-stained images (B and D) are shown. 


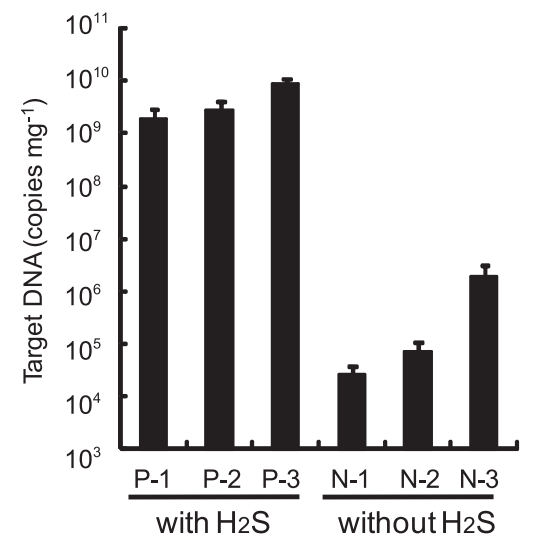

Fig. 5. Quantification of partial 16S rDNA (341-534) using two universal primers by real-time PCR analysis. $\mathrm{P}-1, \mathrm{P}-2$, and $\mathrm{P}-3$ indicate setae samples of crabs cultivated with $\mathrm{H}_{2} \mathrm{~S}$ feeding. N-1, N-2, and N-3 indicate setae samples of crabs cultivated without the feeding. Error bars indicate standard deviations. Chain reactions were performed at least three times.

cultivation for $84 \mathrm{~d}$, microscopy observations and real-time PCR analysis were performed. Microscopy images of representatives of DAPI-stained setae are shown in Fig. 3. The numbers of epibionts on setae after cultivation with $\mathrm{H}_{2} \mathrm{~S}$ feeding (Fig. 4A and $\mathrm{B}$ ) were obviously larger than those without $\mathrm{H}_{2} \mathrm{~S}$ feeding (Fig. $4 \mathrm{C}$ and D). Interestingly, in the images of setae of crabs with feeding, spherical and cocoid epibionts were interestingly found along the filaments. The majority of epibionts on the setae of the crabs collected from the environment are filaments, as shown by previous studies $(27,30)$. The amount of epibionts estimated by real-time PCR analysis is shown in Fig. 5 as the copy number of target DNA (partial 16S rRNA gene) per wet weight of a sample. Three crabs from each cultivating condition were used for the analysis. The amount of epibionts of crabs with feeding reached the target $1.8 \times 10^{9}, 2.7 \times 10^{9}$, and $8.2 \times 10^{9}$ copies per gram of wet weight of setae, whereas those of crabs without $\mathrm{H}_{2} \mathrm{~S}$ feeding reached $2.7 \times 10^{4}, 7.1 \times 10^{4}$, and $1.9 \times 10^{6}$ copies $\mathrm{g}^{-1}$. Although differences in the target DNA copy numbers of individual samples were observed under the same conditions, the number of copies of target DNA of epibionts of crabs with feeding was three orders of magnitude larger than that of crabs without feeding.

\section{Phylogenetic analysis of epibionts}

To determine the phylogenetic affiliation of epibionts on the surface of the setae, phylogenetic analysis was performed on the basis of the partial 16S rDNA sequences. As shown in Fig. 6, thirteen phylotypes of epibionts of the crabs cultivated with $\mathrm{H}_{2} \mathrm{~S}$ feeding were placed in four different phyla, including Alphaproteobacteria, Gammaproteobacteria, and Epsilonproteobacteria and Flavobacteria.

One of the signature episymbiotic bacteria of S. crosnieri, epibiotic phylotype 5, was related to the Sulfurovum-affiliated bacteria group in Epsilonproteobacteria, which was also often detected in different $S$. crosnieri $(27,30)$. It was also related to ectosymbiontic clones isolated from the deep-sea limpet, Symmetromphalus aff. hageni (4), a gill endosymbiont of the hydrothermal vent gastropod, Alviniconcha aff. hessleri (22), ectosymbiont of the hydrothermal shrimp,

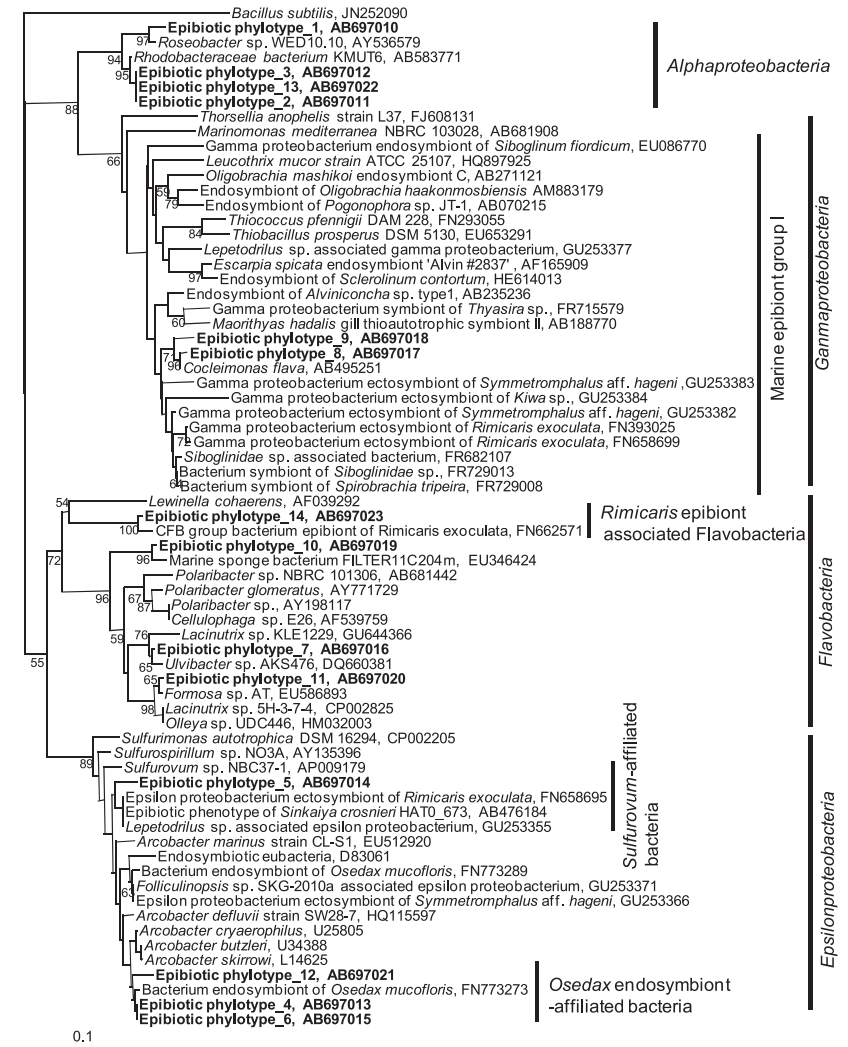

Fig. 6. Phylogenetic tree of epibionts of $S$. crosnieri based on partial 16S rRNA gene sequences (193 nucleotides). Bootstrap values (in percent values) are based on 1,000 replicates of the neighbor-joining method and show more than $50 \%$ bootstrap support.

Rimicaris exoculata (5), and a deep-sea snail of a Lepetodrilus associated Epsilonproteobacterium (4).

In this study, other phylotypes were also detected in Epsilonproteobacteria, as a bone-eating worm Osedax mucofloris endosymbionts-related phylotypes, namely, Osedax mucofloris endosymbiont-affiliated bacteria (29). There was no description of the endosymbiont in Epsilonproteobacteria affiliated to Osedax mucofloris in a recent paper (29). An Arcobacter sp. of the most closely related isolate is a cold-adapted mesophilic and heterotrophic bacterium (28). Species in the genera Arcobacter are often detected from deep sea sulfur mats near and on seeps (16). The phylotypes are thought to be deep sea sulfur oxidizers.

Other signature episymbiotic bacteria of $S$. crosnieri are well known to cluster, namely, marine epibiont group I (30), belonging to the phylum of Gammaproteobacteria. Epibiotic phylotype 8 and 9 are located in marine epibiont group I, although the most closely related sequence is that of Cocleimonas flava (GenBank Accession AB49521) isolated from the sand snail Umbonium costatum, which lives by burrowing into shallow sand or mud (23). Various sequences related to the symbionts of deep-sea invertebrates close to the phylotypes were located as the Thyasira sp. symbiont (19), Marithyas hadalis gill thioautotrophic symbionts (3), Alviniconcha sp. type I endosymbiont (22), Siboglinum fiordicum endosymbionts (24), Oligobrachia haakonmosbiensis endosymbiont (13), Kiwa sp. ectosymbiont (4), Symmetromphalus aff. hageni ectosymbiont (4), Spirobrachia tripeira symbiont (20), and Rimicaris sp. 
ectosymbiont (5), which seem to be putative sulfur-oxidizing bacteria.

Epibiotic phylotype 14 was detected in the phylum of flavobacteria. The most related sequence was that of an epibiont of Rimicaris exoculata, namely, Rimicaris epibiontassociated Flavobacteria (5). Furthermore, the other phylotypes were located near those of free-living Alphaproteobacteria and Flavobacteria. Epibiotic phylotypes 7 and 11 were related to Formosa sp. (14), which were detected by denaturing gradient gel electrophoresis analysis of a commercial shallow raceway marine recirculation system, and related to Lacinutrix sp. strain 5H-3-7-4 (8), which is a polysaccharide-degrading strain isolated from the subseafloor sediments. All of the phylotypes belonging to Alphaproteobacteria were related to the species of rhodobacterales, which are often isolated from marine environments as determined on the basis of GenBank information. The putative free-living bacteria were observe as spherical and cocoid by microscopy.

\section{Phylogenetic analysis of biofilms}

During the cultivation experiment, white bacterial mats and films accumulated on the surfaces of the bed of sea sand in the $\mathrm{H}_{2} \mathrm{~S}$ feeding device and tank wall (Fig. 3A and B). The DAPI-stained films were then observed by microscopy (Fig. 3C and D). The biofilms seemed to consist of bacterial consortia; therefore, phylogenetic analysis was carried out to examine the profile of the growth-stimulated bacteria in biofilm, which were collected from the tank wall $70 \mathrm{~d}$ after the start of cultivation. The phylogenetic tree of consortia in the biofilms is shown in Fig. 7. Fourteen biofilm phylotypes were located in Gammaproteobacteria and Epsilonproteobacteria and Flavobacteria; however, no phylotype belonging to Alphaproteobacteria was detected.

Phylotypes were categorized into the following groups: Rimicaris epibiont-associated Flavobacteria, biofilm phylotype 14; Sulfurovum-affiliated bacteria, biofilm phylotype 5; and Osedax mucofloris endosymbiont-affiliated bacteria, biofilm phylotypes 1, 7, 11, and 13. Interestingly, seven phylotypes were closely related to the sequences of endosymbionts of Alviniconcha sp. type 2 (22), and hydrothermal vent eubacterium PVB_OTU_6, with sequence identities of less than $96 \%$. Phylotypes that clustered with endosymbiont sequences were detected from snails collected from the Vienna Woods site, Manus Basin, $3^{\circ} 9.8^{\prime} \mathrm{S} / 150^{\circ} 16.7^{\prime} \mathrm{E}, 2510$ $\mathrm{m}$. The clade was named group B in a previous study (22).

Biofilm phylotype 3 of Gammaproteobacteria was closely related to free-living Thiomicrospira species with $96 \%$ sequence identity; therefore, the phylotype was derived from free-living Thiomicrospira sp and was different from marine epibiont group I.

\section{Discussion}

To investigate the effects of hydrogen sulfide feeding on epibiotic communities on the surface of the deep-sea crab, $S$. crosnieri, a rearing tank with an $\mathrm{H}_{2} \mathrm{~S}$-supply mechanism was developed in this study for the first time. The crabs and epibionts were cultivated for $84 \mathrm{~d}$ using the tank system, and the structures of epibionts and bacterial mats obtained secondarily were analyzed by microscopy, real-time PCR analysis, and phylogenetic analyses.

Kawagucci et al. (7) reported that $\mathrm{H}_{2} \mathrm{~S}$ was not detected near the Bathymodious colony in the Iheya North field; however, the quantification of $\mathrm{H}_{2} \mathrm{~S}$ in natural environments, especially in the deep sea, is difficult in terms of accuracy because as a reducing agent, $\mathrm{H}_{2} \mathrm{~S}$ spontaneously oxidizes during a long sampling period; therefore, there is possibility that the estimation was affected by spontaneous oxidization. This is one reason why there are few detailed reports on the effects of $\mathrm{H}_{2} \mathrm{~S}$ on the invertebrates and microorganisms in the deep sea. We developed a simple semiconductor gas sensor and on-off control system attached to the rearing tank, and controlled $\mathrm{H}_{2} \mathrm{~S}$ at a specific concentration, between 5 and $40 \mu \mathrm{mol} \mathrm{L}{ }^{-1}$ during two distinguishable periods excluding the period when the cooling unit malfunctioned. From our cultivation experiments (Fig. 2A), $\mathrm{H}_{2} \mathrm{~S}$ at concentrations lower than $40 \mu \mathrm{mol} \mathrm{L}^{-1}$ was continuously provided under a microaerobic condition of DO concentrations between 1.0 and $1.5 \mathrm{mg} \mathrm{L}^{-1}$, which corresponds to saturation between 8.12 and $12.2 \%$ at $5.2^{\circ} \mathrm{C}$. These conditions stimulated the growth of deep-sea chemoautotrophs related to symbionts in this study. Based on the findings, therefore, the conditions may be representative conditions near hydrothermal vents in the deep sea, where chemoautotrophic ecosystems are located. In other words, $\mathrm{H}_{2} \mathrm{~S}$ concentrations near the hydrothermal vents may be higher than those estimated by sampling analyses. The physical and chemical conditions for their growth, obtained from this experiment, will also be significant information for the isolation of deep-sea chemoautotrophs.

From the microscopy findings (Fig. 4) and real-time PCR analysis (Fig. 5) of the surfaces of setae, the growth of epibiotic bacteria appeared to be stimulated by a low concentration of $\mathrm{H}_{2} \mathrm{~S}$, as determined by the comparison between the two different cultivations with and without $\mathrm{H}_{2} \mathrm{~S}$ feeding. Furthermore, phylogenetic analysis of epibionts (Fig. 6) showed that the rearing tank system increased not only the number of episymbionts such as Sulfurovumaffiliated bacteria and marine epibiont group I but also Rimicaris- and Osedax-affiliated symbiont groups along with several free-living heterotrophic bacteria. According to the results, putative sulfur-oxidizing bacteria belonging to Sulfurovum-affiliated bacteria and marine epibiont group I seem to operate via sulfur-oxidizing respiration by using $\mathrm{H}_{2} \mathrm{~S}$ and its spontaneously oxidized compounds including sulfur, thiosulfate, and sulfite, in the artificial deep sea environment at a low temperature and a low DO concentration with $\mathrm{H}_{2} \mathrm{~S}$ provided continuously. A deep-sea isolate Sulfurovum sp. NBC37-1, which is related to an episymbiont of $S$. crosnieri, was reported to be able to use elemental sulfur as both an electron acceptor and donor via its hydrogen-sulfur respiration and thiosulfate-oxidizing nitrate/oxygen respiration pathway under "mixing zone" conditions, where the redox condition shifted from reductive to oxidative, near a hydrothermal vent corresponding to the present artificial condition (17). Rimicaris-affiliated bacteria belonging to Flavobacteria and Osedax-affiliated symbiont groups belonging to Epsilonproteobacteria seemed to be cold-adapted mesophilic and heterotrophic bacteria. These bacteria may secondarily grow using metabolites from chemoautotrophs and the crabs.

Phylogenetic analysis of biofilms (Fig. 7) showed that 


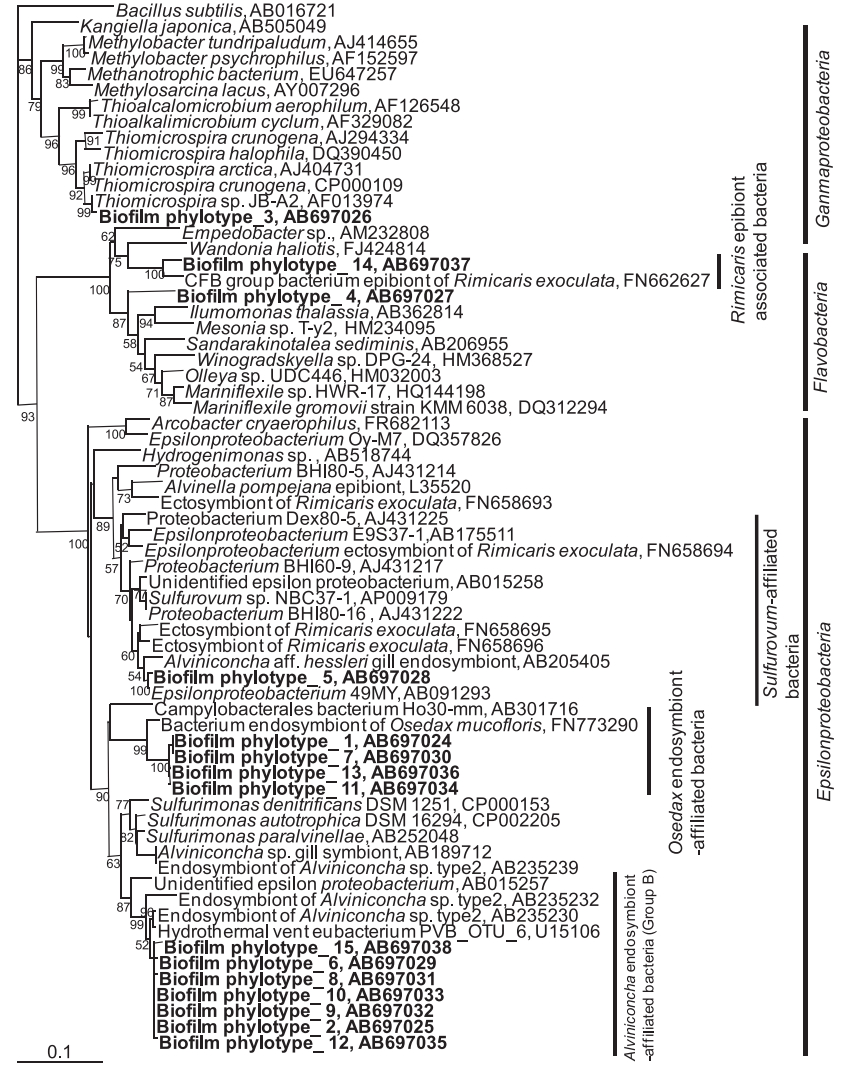

Fig. 7. Phylogenetic tree of members of biofilm based on nearcomplete 16S rRNA gene sequences (1,160 nucleotides). Bootstrap values (in percent values) are based on 1,000 replicates of neighborjoining method and show more than $50 \%$ bootstrap support.

the phylotypes belong to Rimicaris epibiont-associated Flavobacteria, Sulfurovum-affiliated bacteria, and Osedax mucofloris endosymbiont-affiliated bacteria, which correspond to the above results of the analysis of epibionts (Fig. $6)$. Growth of these bacteria would depend on chemical and physiological conditions other than gravitational pressure, and host-symbiont linkages might not necessarily be a significant factor. On the other hand, marine epibiont group I belonging to Gammaproteobacteria, which have been detected in epibiont phylotypes, was not detected. This finding implies that marine epibiont group I tightly bind to their host by a physiological linkage, not only because of environmental factors. Interestingly, one of the major clades of phylotypes was closely related to an endosymbiont of the snail, Alviniconcha sp. type II, which was collected from the Vienna Woods site, Manus Basin, whereas the Iheya North field in the Okinawa Trough is located approximately 3,700 $\mathrm{km}$ from the Vienna Woods site. The other related sequences that were obtained from environmental samples were also collected from the deep sea near the Hawaiian Islands. Significant growth factors for these bacteria are the chemical and physical conditions.

There are a lot of reports about the host-symbiont linkage of invertebrates through field work approaches $(2-5,13,17$, $19,20,22,24,27,29$, and 30). Such approaches pose difficulty in clarifying the cause-effect relationship between growth factors and bacterial growth. In the present study, we were able to examine preliminarily the effects of $\mathrm{H}_{2} \mathrm{~S}$ on the deep- sea crab $S$. crosnieri and its episymbionts in the laboratory, using our own novel rearing tank. Our rearing tank system will be a powerful tool for understanding the host-symbiont linkages of invertebrates inhabiting areas near deep-sea vents, particularly the bivalves, Calyptogena spp., which are considered to possess a strong host-symbiont linkage because of the reduced genome of the symbiont (10). Further developments of cultivation experiments are important for studies of deep-sea invertebrates and microorganisms. Further results of cultivating organisms will be described elsewhere in the future.

\section{Acknowledgements}

We thank the captains and crews of the R/V Natsushima and HyperDolphin for their technical expertise. We thank Ms. Akiko Shiraishi and Ms. Miyuki Takeda for data sampling. We thank Ms. Miho Hirai for technical advice about real-time PCR analysis. This work was supported by JSPS KAKENHI (24657023).

\section{References}

1. Baba, K., and A.B. Williams. 1998. New galatheoidea (Crustacea, Decapoda, Anomura) from hydrothermal systems in West Pacific Ocean: Bismark Archipelago and Okinawa Traugh. Zoosystema 20:143-156.

2. Dubilier, N., C. Bergin, and C. Lott. 2008. Symbiotic diversity in marine animals: the art of harnessing chemosynthesis. Nat. Rev. Microbiol. 6:725-740.

3. Fujiwara, Y., C. Kato, N. Masui, K. Fujikura, and S. Kojima. 2001. Dual symbiosis in a cold seep thyasirid clam Maorithyas hadalis from the hadal zone in the Japan Trench, western Pacific. Mar. Ecol. Prog. Ser. 214:151-159.

4. Goffredi, S.K. 2010. Indigenous ectosymbiotic bacteria associated with diverse hydrothermal vent invertebrates. Environ. Microbiol. Rep. 2:479-488.

5. Hügler, M., J.M. Petersen, N. Dubilier, J.F. Imhoff, and S.M. Sievert. 2011. Pathway of carbon and energy metabolism of the epibiotic community associated with the deep-sea hydrothermal vent shrimp Rimicaris exoculata. Plos One 6:e16018.

6. Katakura, Y., W. Zhang, G. Zhuang, T. Omasa, M. Kishimoto, Y. Goto, and K. Suga. 1998. Effect of methanol concentration on the production of human b2-glycoprotein I domain $\mathrm{V}$ by a recombinant Pichia pastoris: a simple system for the control of methanol concentration using a semiconductor gas sensor. J. Ferment. Bioeng. 86:482487.

7. Kawagucci, S., H. Chiba, J. Ishibashi, et al. 2011. Hydrothermal fluid geochemistry at the Iheya North field in the mid-Okinawa Trough: implication for oritgin of methane in subseafloor fluid circulation systems. Geochem. J. 45:109-124.

8. Klippel, B., A. Lochner, D.C. Bruce, et al. 2011. Complete genome sequences of Krokinobacter sp. strain 4H-3-7-5 and Lacinutrix sp. strain $5 \mathrm{H}-3-7-4$, polysaccharide-degrading members of the family Flavobacteriaceae. J. Bacteriol. 193:4545-4546.

9. Konishi, M., M. Kishimoto, T. Omasa, Y. Katakura, S. Shioya, and H. Ohtake. 2005. Effect of sulfur sources on specific desulfurization activity of Rhodococcus erythropolis KA2-5-1 exponential fed-batch culture. J. Biosci. Bioeng. 99:259-263.

10. Kuwahara, H., T. Yoshida, Y. Takaki, et al. 2007. Reduced genome of the thioautotrophic intracellular symbiont in a deep-sea clam, Calyptogena okutanii. Curr. Biol. 17:881-886.

11. Lane, D.J. 1991. $16 \mathrm{~S} / 23 \mathrm{~S}$ sequencing, p. 115-175. In E. Stackebrandt, and M. Goodfellow (ed.), Nucleic Acid Techniques in Bacterial Systematic. Wiley in Chichester, New York, NY.

12. Larkin, M.A., G. Blackshields, N.P. Brown, et al. 2007. Clustal W and Clustal X version 2.0. Bioinformatics 23:2947-2948.

13. Lösekann, T., A. Robador, H. Niemann, K. Knittel, A. Boetius, and N. Dubilier. 2008. Endosymbioses between bacteria and deep-sea siboglinid tubeworms from an Arctic Cold Seep (Haakon Mosby Mud Volcano, Barents Sea). Environ. Microbiol. 10:3237-3254. 
14. Matos, A., M-T. Borges, C. Peixe, I. Henriques, C.M. Pereita, and P.M.L. Castro. 2011. A molecular and multivariate approach to the microbial community of a commercial shallow raceway marine recirculation system operating with a moving bed biofilter. Aquacult. Res. 42:1308-1322.

15. Miyake, H., M. Kitada, S. Tsuchida, Y. Okuyama, and K. Nakamura 2007. Ecological aspects of hydrothermal vent animals in captivity at atmospheric pressure. Mar. Ecol. 28:86-92.

16. Moussard, H., E. Corre, M.A. Cambon-Bonavita, Y. Fouquet, and C. Jeanthon. 2006. Novel uncultured Epsilonproteobacteria dominate a filamentous sulphur mat from the 13 degrees $\mathrm{N}$ hydrothermal vent field, East Pacific Rise. FEMS Microbiol. Ecol. 58:449-463.

17. Nakagawa, S., Y. Takaki, S. Shimamura, A-L. Reysenbach, and K. Takai. 2007. Deep-sea vent $\varepsilon$-proteobacterial genomes provide insights into emergence of phathogens. Proc. Natl. Acad. Sci. U.S.A. 104:12146-12150.

18. Nakagawa, S., and K. Takai. 2008. Deep-sea vent chemoautotrophs: diversity, biochemistry and ecological significance. FEMS Microbiol. Ecol. 65:1-14.

19. Rodrigues, C.F., and S. Duperron. 2011. Distinct symbiont lineages in three thyasirid species (Bivalvia: Thyasiridae) from the eastern Atlantic and Mediterranean Sea. Naturwissenschaften. 98:281-287.

20. Rodrigues, C.F., A. Hilário, M.R. Cunha, A.J. Weightman, and G. Webster. 2011. Microbial diversity in Frenulata (Siboglinidae, Polychaeta) species from mud volcanoes in the Gulf of Cadiz (NE Atlantic). Antonie Van Leeuwenhoek 100:83-98.

21. Saito, H. 2011. Characteristics of fatty acid composition of the deep-sea vent crab, Shinkaia crosnieri Baba and Williams. Lipid 46:723-740.

22. Suzuki, Y., T. Sasaki, M. Suzuki, Y. Nogi, T. Miwa, K. Takai, K.H. Nealson, and K. Horikoshi. 2005. Novel chemoautotrophic endosymbiosis between a member of the Epsilonproteobacteria and hydrothermal-vent gastropod Alviniconcha aff. hessleri (gastropoda: provanidae) from the Indian Ocean. Appl. Environ. Microbiol. 71:5440-5450.

23. Tanaka, N., L.A. Romanenko, T. Lino, G.M. Frolova, and V.V. Mikhailov. 2011. Cocleimonas flava gen. nov., a gammaproteobacterium isolated from sand snail (Umbonium costatum). Int. J. Syst. Evol. Microbiol. 61:412-416.
24. Thornhill, D.J., A.A. Wiley, A.L. Campbell, F.F. Bartol, A. Teske, and K.M. Halanych. 2008. Endosymbionts of Siboglinum fiordicum and the phylogeny of bacterial endosymbionts in siboglinidae (Annelida). Biol. Bull. 214:135-144.

25. Tokeshi, M. 2011. Spatial structures of hydrothermal vents and vent-associated megafauna in the back-arc basin system of the Okinawa Trough, western Pacific. J. Oceanogr. 67:651-665.

26. Tsuchida, S., Y. Fujiwara, and K. Fujikura. 2003. Distribution and population structure of the galatheid crab Shinkaia crosnieri (Decapoda: Anumoura: Galatheidae) in the Southern Okinawa Trough. Jpn. J. Benthol. 58:84-88.

27. Tuchida, S., Y. Suzuki, Y. Fujiwara, M. Kawato, K. Uematsu, T. Yamanaka, C. Mizota, and H. Yamamoto. 2011. Epibiotic association between filamentous bacteria and the vent-associated galatheid crab, Shinkaia crosnieri (Decapoda: Anomura). J. Mar. Biol. Assoc. U. K. 91:23-32.

28. Vandamme, P., E. Falsen, R. Rossau, B. Hoste, P. Segers, R. Tytgat, and J. DeLey. 1991. Revision of Campylobacter, Helicobacter and Wolinella taxonomy: emendation of genetic descriptions and proposal of Arcobacter gen. nov. Int. J. Syst. Bacteriol. 41:88-103.

29. Verna, C., A. Ramette, H. Wiklund, T.G. Dahlgren, A.G. Glover, F. Gail, and N. Dubilier. 2010. High symbiont diversity in the boneeating worm Osedax mucofloris from shallow whale-falls in the North Atlantic. Envion. Microbiol. 12:2355-2370.

30. Watsuji, T., S. Nakagawa, S. Tsuchida, T. Toki, A. Hirota, U. Tsunogai, and K. Takai. 2010. Diversity and function of epibiotic microbial communities on the galatheid crab, Shinkaia crosnieri. Microbes Environ. 4:288-294.

31. Yamamoto, M., S. Nakagawa, S. Shimamura, K. Takai, and K. Horikoshi. 2010. Molecular characterization of inorganic sulfurcompound metabolism in the deep-sea epsilonproteobacterium Sulfurovum sp. NBC37-1. Environ. Microbiol. 12:1144-1153.

32. Yuan, Y.J., and H. Kuriyama. 2000. Determination of hydrogen sulfide in a yeast culture solution by flow analysis utilizing methylen blud spectrophotometric detection. Biotechnol. Lett. 22:795-799. 